\title{
Prohormone convertases $1 / 3$ and 2 together orchestrate the site-specific cleavages of progastrin to release gastrin-34 and gastrin-17
}

Jens F. REHFELD ${ }^{* 1}$, Xiaorong $\mathrm{ZHU}^{++}$, Christina NORRBOM ${ }^{++}$, Jens R. BUNDGAARD ${ }^{*}$, Anders $H$. JOHNSEN*, John E. NIELSEN ${ }^{+}$, Jonas VIKESAA*, Jeffrey STEIN++, Arunangsu DEY++, Donald F. STEINER ${ }^{++}$, Lennart FRIIS-HANSEN*

*Departments of Clinical Biochemistry and ${ }^{+}$Growth \& Reproduction, Rigshospitalet, University of Copenhagen, Denmark, and ${ }^{++}$The Department of Biochemistry \& Molecular Biology, and Howard Hughes Medical Institute, University of Chicago, Illinois 60637, USA

Corresponding author:

Professor Jens F. Rehfeld Copenhagen University Hospital Department of Clinical Biochemistry, KB-3014 9 Blegdamsvej DK-2100 Copenhagen

Tel: $+45-35453018$

Fax: $+45-35454640$ jens.f.rehfeld@rh.regionh.dk 


\section{SYNOPSIS}

Cellular synthesis of peptide hormones requires prohormone convertases (PCs) for the endoproteolysis of prohormones. Antral G-cells synthesize most gastrin and express $\mathrm{PC} 1 / 3,2$ and 5/6 in rat and man. But the cleavage sites in progastrin for each PC have not been determined. Therefore, we measured the concentrations of progastrin, processing intermediates and $\alpha$-amidated gastrins in antral extracts from $\mathrm{PC} 1 / 3$ null-mice and compared the results to those in mice lacking PC2 and wild-type controls. The expression of PCs was examined by immunocytochemistry and in situ hybridisation of mouse G-cells. Finally, the in vitro effect of recombinant PC5/6 on progastrin and progastrin fragments containing the relevant dibasic cleavage sites was also examined. The results showed that also mouse G-cells express PC1/3, 2 and 5/6. The concentration of progastrin in PC1/3 null-mice was threefold elevated. Chromatography showed that cleavage of the $\mathrm{R}_{36} \mathrm{R}_{37}$ and $\mathrm{R}_{73} \mathrm{R}_{74}$ sites were grossly decreased. Accordingly, the concentrations of progastrin products were markedly reduced, $\alpha$-amidated gastrins (-34 and 17) being $25 \%$ of normal. Lack of $P C 1 / 3$ was without effect on the third dibasic site $\left(\mathrm{K}_{53} \mathrm{~K}_{54}\right)$, which is the only processing site for PC2. Recombinant PC5/6 did not cleave any of the dibasic processing sites in progastrin and fragments containing the relevant dibasic processing sites. The complementary cleavages of $\mathrm{PC} 1 / 3$ and 2 , however, suffice to explain most of the normal endoproteolysis of progastrin. Moreover, the results show that prohormone convertases react differently to the same dibasic sequences, suggesting that additional structural factors modulate the substrate specificity.

Short title: Prohormone convertases in gastrin biosynthesis

Key words: biosynthesis, gastrin, peptide hormones, posttranslational processing, progastrin, prohormone convertases

\section{INTRODUCTION}

Gastrin is a gastrointestinal hormone that regulates gastric acid secretion and mucosal cell growth [for review, see ref. 1]. Most gastrin is synthesized in antral G-cells where progastrin through multiple steps is processed to $\alpha$-amidated gastrins of different lengths (Figure 1). Of these, gastrin-34 and gastrin-17 predominate in normal tissue and circulation. Their synthesis requires cleavage of three evolutionary conserved dibasic sequences in progastrin: $\mathrm{R}_{36} \mathrm{R}_{37}, \mathrm{~K}_{53} \mathrm{~K}_{54}$ and $\mathrm{R}_{73} \mathrm{R}_{74}$ [2-6]. Outside antrum the gastrin gene is expressed at low levels in the small intestinal mucosa, in the fetal pancreas, in pituitary corticotrophs and melanotrophs, in hypothalamo-pituitary neurons and in spermatozoes [7-11] as well as in a number of common cancers [for review, see ref. 12]. The extra-antral processing of progastrin is often cell-type specific. For instance, there is no cleavage of the $\mathrm{K}_{53} \mathrm{~K}_{54}$ site in neither pituitary corticotrophs nor ileal TG-cells $[13,14]$.

The G-cell maturation of progastrin requires several processing enzymes (Figure 1). While the involvement of tyrosyl protein sulfotransferases, carboxypeptidase $\mathrm{E}$ and the amidating enzyme complex (peptidylglycyl $\alpha$-amidating monooxygenase (PAM)) appears well-established [15-18], the role of the individual prohormone convertase (PC) remains to be settled. Mammals express seven basic amino acid specific PCs of which PC1/3 and 2 are assumed to be involved primarily in endoproteolytic processing of neuroendocrine proproteins [for reviews, see refs. 19-21]. Both PC1/3 and PC2 have been demonstrated by immunocytochemistry in human and rat antral G-cells $[22,23]$ and, at mRNA level, in rat antral extracts [24]. PC5/6, however, also appears to be neuroendocrine as it is expressed in gastrointestinal endocrine cells and cerebral neurons $[23,25,26]$. Accordingly, small amounts of PC5/6 mRNA were also detected in extracts of the rat antrum, and immunoreactive PC5/6 demonstrated in rat antral G-cells [23,24].

Recently, we showed in $\mathrm{PC} 2$ and 7B2 knockout mice that $\mathrm{PC} 2$ plays a distinct role limited to partial cleavage of the $\mathrm{K}_{53} \mathrm{~K}_{54}$ site of progastrin [27]. Hence, PC2 determines the concentrations and ratio between the two primary gastrins, gastrin-34 and gastrin-17. But PC2 was without effect on any of the two di-arginyl sites of which processing of the latter, $R_{73} R_{74}$, is decisive for production of bioactive gastrins (Figure 1). In the present study we have examined the roles of $\mathrm{PC} 1 / 3$ and $\mathrm{PC} 5 / 6$, which became possible with the development of mice lacking PC1/3 [28], and the availability of active recombinant PC5/6. Taken together, the results should reflect the normal endoproteolytic profile of progastrin processing in antral G-cells since no other PCs are expressed in endocrine G-cells. 


\section{EXPERIMENTAL}

\section{Mice}

The PC1/3 null mutant mice were generated as described earlier [28]. For the present study, tissue was obtained from 12-week-old $\mathrm{PC} 1 / 3$ null mice and wild-type $(+/+)$ littermates of the same age. The care and treatment of all animals were in accordance with NIH and institutional guidelines.

\section{Tissue isolation and extraction}

Mice in groups of four were sacrificed by $\mathrm{CO}_{2}$ inhalation, and stomach tissue was rapidly dissected and frozen on dry ice. The tissue was gently rinsed in phosphatebuffered saline on ice before freezing. Tissue extracts for radioimmunoassay (RIA) were prepared as previously described [29]. Briefly, frozen tissues were boiled in water $(1 \mathrm{ml} / \mathrm{mg})$ for $20 \mathrm{~min}$, homogenized (polytron) and centrifuged for $30 \mathrm{~min}$ at $10,000 \mathrm{rpm}$. The supernatants were withdrawn and the pellets re-extracted in $0.5 \mathrm{M}$ $\mathrm{CH}_{3} \mathrm{COOH}$ (1 $\left.\mathrm{ml} / \mathrm{mg}\right)$, rehomogenized, incubated at room temperature for $30 \mathrm{~min}$ and centrifuged. The neutral water and acid supernatants were stored at $-20^{\circ} \mathrm{C}$ until RIA analysis. The acid extracts, however, turned out to contain only negligible amounts of progastrin and its products. Consequently they were not included in further examinations.

\section{Chromatography}

One or two $\mathrm{ml}$ of extracts were applied to Sephadex G-50 superfine columns $(10 \times 1,000 \mathrm{~mm})$ which were eluted at $4^{\circ} \mathrm{C}$ with $0.02 \mathrm{M}$ barbital buffer, $\mathrm{pH} 8.4$, containing $0.1 \%$ bovine serum albumin. Fractions of $1.0 \mathrm{ml}$ were collected at a rate of $4.0 \mathrm{ml} / \mathrm{h}$. The columns were calibrated with $\left[{ }^{125}\right.$ I] albumin (void volume), gastrin-34 and gastrin-17, and with ${ }^{22} \mathrm{NaCl}$ (total volume). The eluted fractions were assayed with a library of sequence-specific radioimmunoassays against different progastrin epitopes and fragments using antibodies nos. 2604, 2605, 8017, 2145, 5284, and 3208, as detailed below. The percentages of carboxyamidated gastrin were calculated by planimetry. Four different extracts from each of the two groups of mice ( $\mathrm{PC} 1 / 3$ knockout, and corresponding wild-type controls) were subjected to gel chromatography.

\section{Radioimmunoassays}

A library of six sequence-specific antisera against progastrin and its fragments was used to measure the different forms of gastrin and progastrin processing intermediates (Figure 1). The sum of carboxyamidated gastrins was measured using the gastrin-specific antiserum no. 2604, $\left[{ }^{125} \mathrm{I}\right]$ gastrin-17 as tracer and gastrin-17 as standard. Antibody no. 2604 binds the carboxyamidated gastrin-34 and gastrin-17 with equimolar affinity, irrespective of size and degree of tyrosyl O-sulfation [30]. The crossreactivity with homologous cholecystokinin peptides is negligible [30,31]. Non-sulfated carboxyamidated gastrin-34 and -17 were measured in parallel using antibody no. 2605 [32]. Glycine-extended processing intermediates of progastrin were measured using antisera nos. 5284 and 3208 with $\left[{ }^{125} \mathrm{I}\right]$ glycine-extended gastrin-17 as tracer and glycine-extended gastrin-17 as standard [33]. Glycine-arginine-extended intermediate precursors were measured using antiserum nos. 5284 and 3208 following enzymatic pretreatment with only carboxypeptidase B [33]. To measure all precursor forms of gastrin, samples were pretreated with both trypsin and carboxypeptidase B followed by radioimmunoassay measurement using antiserum no. 5284, as previously described [33]. Carboxypeptidase $\mathrm{B}$ mimics the effect of carboxypeptidase $\mathrm{E}$, while trypsin mimics the effects of PCs. Antiserum no. 2145 was used to measure fragment 38-52 of human progastrin, corresponding to the pyroglutaminated $\mathrm{N}$ terminus of gastrin-34 using $\left[{ }^{125} \mathrm{I}\right]$ gastrin-34 as tracer and gastrin-34 as standard [34]. Correspondingly, antiserum no. 8017 was used to measure the pyroglutaminated Nterminus of human gastrin-17 using $\left[{ }^{125} \mathrm{I}\right]$ gastrin-17 as tracer and gastrin-17 as standard [35]. Due to species differences in the $\mathrm{N}$-terminal sequences of mammalian gastrin-34 and -17 , it was necessary to use antisera nos. 2145 and 8017 for characterization of possible progastrin cleavage products after incubation of human progastrin with recombinant PC5/6. To monitor the purification of recombinant human progastrin, we also used a radioimmunoassay based on antiserum no. 94023 directed against the very $\mathrm{N}$-terminus of human progastrin together with the corresponding $\mathrm{N}$-terminal decapeptide fragment tyrosylated at its C-terminus as tracer and standard [36].

\section{In vitro cleavage of progastrin and progastrin fragments with recombinant PC5/6A}

To produce recombinant human progastrin, an expression vector of human preprogastrin, as previously described [37], was transiently transfected into $\mathrm{CHO}$ cells using a standard Fugene6 transfection protocol (Roche Applied Science). After $48 \mathrm{~h}$, culture media was recovered, separated by gel filtration on a 1000x $50 \mathrm{~mm}$ Superdex G50 Superfine column and eluted, as previously described [37]. Recovered fractions were analysed for progastrin using the radioimmunoassay specific to the N-terminus of human progastrin [36]. Fractions eluting at the position of intact progastrin were pooled and subjected to an 
in vitro PC5/6A cleavage assay. Half of the peptide pool was added 10 units of human PC5/6 (Phenoswitch Bioscience Inc., Sherbrooke, Canada) and reaction buffer to a concentration as suggested by Phenoswitch Bioscience (vide intra) and incubated for 4 hours at $37^{\circ} \mathrm{C}$. A control pool was only added reaction buffer and incubated like the reaction pool. Both pools were subjected to gel filtration and analysed using specific radioimmunoassays towards the N-terminals of progastrin, gastrin-34 and gastrin-17 as well as C-terminal assay against glycineextended gastrin $[30,33,34,36]$.

Gastrin-34 from Sigma and the peptides GPASHHRRQLGPQGP (progastrin cleavage site for gastrin-34 N-terminus) and PEELVHRVKRRADPDPMK (PC substrate [38]) were custom synthesized by Schafer-N (Copenhagen, Denmark). Incubation of the peptides were performed as suggested by PhenoSwitch in a total volume of $100 \mu \mathrm{l} 20$ $\mathrm{mM}$ Bis-Tris buffer $\mathrm{pH} 6.5$, containing $1 \mathrm{mM} \mathrm{CaCl}{ }_{2}$, BSA $(2 \mathrm{~g} / \mathrm{l}), 100 \mu \mathrm{M}$ peptide (substrate) and $10 \mathrm{U}$ of $\mathrm{PC} 5 / 6$ for $2 \mathrm{~h}$ at $37^{\circ} \mathrm{C}$. The reaction was terminated by addition of $10 \mu 110 \%$ trifluoroacetic acid. The reaction mixture was separated by HPLC using a $2.1 \times 150 \mathrm{~mm}$ C18 column (Vydac, Hisperia, USA) eluted with a gradient from $10-40 \%$ acetonitrile over $30 \mathrm{~min}$, the elution buffers contained $0.1 \%$ trifluoroacetic acid. The chromatograms were monitored at $214 \mathrm{~nm}$ and peaks were collected manually. The peptides collected were analysed by MALDI-TOF mass spectrometry (AutoFlex II, Bruker, Bremen, Germany) using $\alpha$-cyano- 4 hydroxycinnamic acid as matrix.

\section{Immunocytochemistry}

To examine the cellular co-localization between gastrin and $\mathrm{PC} 1 / 3$ or $\mathrm{PC} 2$, the stomach was removed from three wild-type mice aged 3-4 months, cut open, washed, and immersion fixed overnight in $4 \%$ paraformaldehyde. Six $\mu \mathrm{m}$ traverse paraffin sections were cut, mounted on superfrosted glass slides and baked overnight at $60^{\circ} \mathrm{C}$. Antigen retrieval was performed by boiling the slides in a microwave oven for 3 minutes at $800 \mathrm{~W}$, followed by 3 times 5 minutes at $400 \mathrm{~W}$ in a $10 \mathrm{mM}$ Tris-buffered EGTA solution at $\mathrm{pH}$ 9.0. Preblocking was performed in $10 \%$ ovine serum in TBS for 20 minutes. The sections were incubated with PC1/3 or PC2 antisera diluted 1:10,000 overnight at $4^{\circ} \mathrm{C}[39,40]$. The primary antiserum was detected with Envision+ (Dako, Glostrup, Denmark) for 1 hr followed by incubation with a Cy3 conjugated antihorseradish perioxidase antibody (Jackson, West Grove, Pennsylvania, USA) diluted 1:400 for $1 \mathrm{hr}$. Gastrin was detected with overnight incubation with antiserum no.
8007 (dilution $1: 1000$ ) at $4^{\circ} \mathrm{C}$ and subsequently reacted to Alexa 488 conjugated donkey-anti rabbit $\mathrm{F}(\mathrm{ab})$-fragments (dilution 1:1000) (Molecular Probes, Inc., Eugene, Oregon, USA). Antiserum no. 8007 is specific to the caboxyamidated C-terminus of the gastrins [31]. Cover slips were mounted with Aquamount (Dako). Analysis of the sections was performed with Zeiss LSM510 confocal microscope (Zeiss, Oberkochen, Germany).

\section{In situ hybridisation}

Serial sections were probed to the PC5/6 antisense probe, gastrin antiserum no. 8007 [31] and PC5/6 sense probe. In situ hybridisation was performed as previously described [41]. In brief, mouse stomach was fixed in $4 \%$ paraformaldehyde, $8 \mu \mathrm{m}$ sections were placed on SuperFrostRPlus slides (Menzel GmbH, Braunschweig Germany), deparaffinised and PFA (4\%) fixed, and treated with proteinase K (P2308; Sigma, St. Louis, Missouri, USA), postfixed ( $4 \% \mathrm{PFA})$, prehybridised for $1 \mathrm{~h}$ at $50^{\circ} \mathrm{C}$, and incubated over night with the labelled PC5/6 probe $\left(50^{\circ} \mathrm{C}\right)$, specific to nucleotide. Visualization was made with anti-digoxigenin-AP (Roche Diagnostics, Mannheim, Germany) and chromogens BCIP (Sigma B-8503) and NBT (Sigma N-6876).

\section{RESULTS AND DISCUSSION}

\section{Progastrin processing in PC1/3 and PC2 knockout mice}

As shown in Table 1 and Figure 2, the antral concentrations of progastrin and its products are grossly altered in $\mathrm{PC} 1 / 3$ knockout mice. The concentration of progastrin itself is increased nearly three-fold, whereas concentrations of the processing intermediates are reduced to one third, and the bioactive, carboxyamidated gastrins are reduced to one fourth of the concentrations in wild-type controls. The reductions contrast the earlier findings in PC2 knockout mice and the carboxypeptidase E-deficient $\left(\mathrm{CPE}^{\mathrm{fat}}\right)$ mice, in which the antral concentrations of the bioactive, carboxyamidated gastrins are maintained at a normal level in spite of major disturbances at earlier steps in the processing pathway and in the ratio between gastrin-34 and gastrin-17 (Table 1, Figure 2 and $[18,27]$ ).

Gel chromatography of neutral antral extracts revealed an unchanged molecular pattern of carboxyamidated gastrins in the $\mathrm{PC} 1 / 3$ knockout mice, despite the marked difference in tissue concentrations (Figure 3). Hence, the ratios between gastrin-34 and gastrin-17, and between tyrosyl-sulfated and non-sulfated gastrins were as in the wildtype controls (Figure 3). The low concentrations ex- 
cluded chromatographic examination of the processing intermediates, but it was possible to study the progastrin immunoreactivity, which showed a significant difference between the null mice and their wild-type littermates (Figure 4). Thus, the progastrin molecule is only partly cleaved at the dibasic $\mathrm{R}_{36} \mathrm{R}_{37}$ site and even less at the $\mathrm{K}_{53} \mathrm{~K}_{54}$ site in the PC1/3 null mice (Figure 4 upper panel), while progastrin in the controls is almost completely processed to shorter fragments (Figure 4 lower panel). The modest differences in antral concentrations of progastrin and its processing products between the three groups of wild-type controls (Table 1) supposedly reflect differences in mouse strains and age. Hence, the mice used in the present study are younger ( 3 months of age) than those used in the studies of carboxypeptidase Edeficiency and PC2 knockout that were up to 6 months of age $[18,27]$. As shown before, the antral concentration of progastrin declines with age in rodents [42].

The processing observed in $\mathrm{PC} 1 / 3$ knockout mice indicates that $\mathrm{PC} 1 / 3$ initiates cleavage at the $\mathrm{N}$-terminal di-arginyl site $\left(\mathrm{R}_{36} \mathrm{R}_{37}\right)$ at an early stage in the processing, since more progastrin and a large fragment corresponding to sequence $38-83$ of progastrin were found in the antral extract of PC1/3 null mice (Figure 4). Subsequently, $\mathrm{PC} 1 / 3$ continues to cleave the $\mathrm{C}$-terminal di-arginyl site $\mathrm{R}_{73} \mathrm{R}_{74}$. PC1/3, however, appears to be without effect on the di-lysyl site, $\mathrm{K}_{53} \mathrm{~K}_{54}$ (Figure 3). This endoproteolytic cleavage pattern of progastrin is opposite to that of $\mathrm{PC} 2$ (Table 1, Figure 2 and [27]). Thus, PC2 only cleaves the single di-lysyl site of progastrin, $\mathrm{K}_{53} \mathrm{~K}_{54}$, the cleavage for half of which PC2 appears to be responsible [27]. The results hence support the contention that $\mathrm{PC} 1 / 3$ generally prefers arginine containing cleavage sites, while PC2 is activated later in the processing pathway to cleave mainly lysine containing dibasic sites at the lower $\mathrm{pH}$ characteristic of mature secretory granules [20].

The present data support our earlier observation that pituitary corticotrophs which contain only $\mathrm{PC} 1 / 3$ and no PC2 cannot process the $\mathrm{K}_{53} \mathrm{~K}_{54}$ site of progastrin. Therefore, corticotrophs synthesize gastrin-34, but no gastrin-17 $[9,10,13]$. This notion is also supported by Sawada el al. who found that PC2 transfected into AtT20 cells but not $\mathrm{PC} 1 / 3$ can accomplish cleavage of the dilysyl site in progastrin [43]. Also proopiomelanocortin (POMC) contains a KK site within $\beta$-endorphin which remains unprocessed in AtT-20 cells but can be processed upon contransfection with PC2 $[44,45]$. However, cleavage of the $\mathrm{KK}$ site within proenkepalin is apparently largely mediated by $\mathrm{PC} 1 / 3$ since it is efficiently cleaved in AtT-20 cells [46]. The primary structure of the three precursors (progastrin, POMC and proenkephalin) re- veals extensive differences in the vicinity of the $\mathrm{KK}$ sites, which could account for the differential ability of PC1/3 to recognize this type of processing site within different contexts.

A surprising finding in the present study was the increased concentration of progastrin in the antrum of PC1/3 null mice, while the concentrations of the processing products were drastically reduced (Table 1 and Figure 2 ). It is obvious that the lack of $\mathrm{PC} 1 / 3$ reduces the processing of progastrin severely. But it is an unsolved question why the total translational product in $\mathrm{PC} 1 / 3$ null mice is reduced, whereas it is increased in other processing enzyme deficiencies [18]. The C-terminal dibasic cleavage sites in progastrin are, however, part of the motif for sorting to the regulated secretory pathway [47]. Moreover, $\mathrm{PC} 1 / 3$ has been shown to enhance the postGolgi sorting of some prohormones [48]. It is therefore possible that the lack of $\mathrm{PC} 1 / 3$ per se reduces the storage of progastrin and its products in the secretory granules of G-cells.

\section{Progastrin cleavage by PC5/6}

Since half of the KK site within progastrin is cleaved in the absence of PC2 [27], and since $30 \%$ of the two diarginyl sites are cleaved in the absence of PC1/3 (Table 1 ), other convertases might participate in the in vivo endoproteolytic processing of progastrin in normal Gcells. A candidate for this activity is PC5/6, which has been shown to be expressed in endocrine cells of the gastrointestinal tract $[25,49]$. As shown here and in the rat, PC5/6 gene expression can be demonstrated in antral Gcells (Figure 7 and [23]). PC5/6 is known to cleave basic processing sites $[19,20]$. In order to examine possible effects of PC5/6, we first looked at the processing of progastrin in SK-N-MC cell line, since PC5/6 knockout mice were not available, and since SK-N-MC cells have been claimed to express the $\mathrm{PC} 5 \mathrm{~A}$ isoform but neither $\mathrm{PC} 1 / 3$ nor PC2 [50]. Resent re-examinations, however, have shown that SK-N-MC cells may indeed express PC1/3 at protein level [Bundgaard $\mathrm{J}$, unpublished results] and also PC2, although without its chaperone 7B2 [Lindberg I, personal communication]. Consequently, we decided to exclude the results obtained of progastrin processing in this cell-line.

Instead we examined directly in vitro the substrate activity of PC5/6 against intact progastrin. Human progastrin was expressed in $\mathrm{CHO}$ cells, which do not cleave progastrin. Progastrin was subsequently purified by size exclusion gel chromatography, and recovered peptide was incubated in vitro with recombinant PC5/6A. Prod- 
ucts were subjected to repeated chromatography and analysed using radioimmunoassays that are specific to the dibasic cleavage sites of human progastrin [34,35]. Enzyme treated progastrin eluted identically to untreated control fractions (Figure 5), and the site-specific radioimmunoassays did not detect processing at any of the cleavage sites. Moreover, digestion with recombinant PC5/6 of gastrin-34 and the synthetic peptide spanning the N-terminus of gastrin-34 within progastrin resulted in no cleavage, while the general PC substrate [38] used as control was cleaved as expected. Consequently, we conclude that PC5/6 is without effect on progastrin, and that the processing of progastrin originally observed in S-K$\mathrm{N}-\mathrm{MC}$ cells is due to other endoproteases than PC5/6.

\section{Prohormone convertase expression in G-cells}

As shown in Figure 6, both PC1/3 and PC2 are expressed in normal antral G-cells in mice. The immunocytochemical results are in accordance with earlier results in human and rat antrum $[22,23]$. In addition, as shown here by in situ hybridisation (Figure 7), also PC5/6 is expressed in murine antral G-cells.

\section{The interplay of PC1/3 and PC2 and the role of PC5/6 in G-cells}

Since no cleavage was found in the in vitro studies using PC5/6 against intact progastrin and progastrin fragments containing the dibasic cleavage sites, whereas the same PC5/6 was fully active in cleaving a control peptide. PC5/6 hardly plays a significant role in the G-cell maturation of progastrin. It is possible that PC5/6 is instead involved in the processing of other neuroendocrine G-cell products such as chromogranin A and neuropeptide W $[51,53]$. Thus, the endoproteolytic maturation of progastrin as seen in normal G-cells appears to require an interplay, primarily between $\mathrm{PC} 1 / 3$ and $\mathrm{PC} 2$. We believe that the processing begins with $\mathrm{PC} 1 / 3$, which is solely responsible for the cleavage of $\mathrm{R}_{36} \mathrm{R}_{37}$. But, subsequently, $\mathrm{PC} 1 / 3$ cleaves the crucial $\mathrm{R}_{73} \mathrm{R}_{74}$. Later, in secretory granules, PC2 performs the partial cleavage of $\mathrm{K}_{53} \mathrm{~K}_{54}$ to ensure the production of gastrin-17.

\section{ACKNOWLEDGEMENTS}

The skilful technical and secretarial assistance of Alice von der Lieth, Rikke Kröncke, Allan Kastrup, and Diana Skovgaard is gratefully acknowledged. The study was supported by grants from the Danish Biotechnology Program for Peptide Research; NIH grants DK-13914, DK20595, and the Howard Hughes Medical Institute.

\section{REFERENCES}

1 Rehfeld, J.F. (1998) The new biology of gastrointestinal hormones. Physiol. Rev. 78, 1087-1108

2 Yoo, O.J., Powell, C.T., and Agarwal, K.L. (1982) Molecular cloning and nucleotide sequence of fulllength of cDNA coding for porcine gastrin. Proc. Natl. Acad. Sci. USA 79, 1049-1053

3 Boel, E., Vuust, J., Norris, F., Norris, K., Wind, A., Rehfeld, J.F., and Marcker, K.A. (1983) Molecular cloning of human gastrin cDNA: evidence for evolution of gastrin by gene duplication. Proc. Natl. Acad. Sci. USA 80, 2866-2869

4 Gregory, R.A., and Tracy, H.J. (1964) The constitution and properties of two gastrins extracted from hog antral mucosa. Gut 5, 103-117

5 Gregory, R.A., and Tracy, H.J. (1972) Isolation of two "big gastrins" from Zollinger-Ellison tumour tissue. Lancet 2,797-799

6 Rehfeld, J.F., and Johnsen, A.H. (1994) Identification of gastrin component I as gastrin-71. The largest possible bioactive progastrin product. Eur. J. Biochem. 223, 765-773

7 Larsson, L.I., and Rehfeld, J.F. (1979) A peptide resembling the $\mathrm{COOH}$-terminal tetrapeptide amide of gastrin from a new gastrointestinal endocrine cell type. Nature 277, 575-578

8 Larsson, L.I., Rehfeld, J.F., Sundler, F., and Håkanson, R. (1976) Pancreatic gastrin in foetal and neonatal rats. Nature 262, 609-610

9 Rehfeld, J.F. (1978) Localisation of gastrins to neuro- and adenohypophysis. Nature 271, 771-773

10 Rehfeld, J.F., and Larsson, L.I. (1981) Pituitary gastrin: Different processing in corticotrophs and melanotrophs. J. Biol. Chem. 256, 10426-10429

11 Schalling, M., Persson, H., Pelto-Huikko, M., Ødum, L., Ekman, P., Gottlieb, C., Hökfelt, T., and Rehfeld, J.F. (1990) Expression and localization of gastrin messenger RNA and peptide in spermatogenic cells. J. Clin. Invest. 86, 660-669

12 Rehfeld, J.F., and van Solinge, W.W. (1994) The tumor biology of gastrin and cholecystokinin. Adv. Cancer Res. 63, 295-347

13 Rehfeld, J.F. (1986) Accumulation of nonamidated preprogastrin and preprocholecystokinin products in porcine pituitary corticotrophs: Evidence of posttranlational control of cell differentiation. J. Biol. Chem. 261, 5841-5847

14 Friis-Hansen, L., and Rehfeld, J.F. (1994) Ileal expression of gastrin and cholecystokinin: In search of a related hormone. FEBS Lett. 343, 115-119

15 Hilsted, L., and Rehfeld, J.F. (1987) Alphacarboxyamidation of antral progastrin: Relation to other post-translational modifications. J. Biol. Chem. 262, 16953-16957

16 Eipper, B.A., Milgram, S.L., Husten, E.J., Yun, H.Y., and Mains, R.E. (1993) Peptidylglycine alphaamidation monooxygenase: a multifunctional protein 
with catalytic, processing, and routing domains. Protein Sci. 2, 489-497

17 Bundgaard, J.R., Vuust, J., and Rehfeld, J.F. (1995) Tyrosine O-sulfation promotes proteolytic processing of progastrin. EMBO J. 14, 3073-3079

18 Lacourse, K.A., Friis-Hansen, L., Rehfeld, J.F., and Samuelson, L.C. (1997) Disturbed progastrin processing in carboxypeptidase E-deficient fat mice. FEBS Lett. 416, 45-50

19 Zhou, A., Webb, G., Zhu, X., and Steiner, D.F. (1999) Proteolytic processing in the secretory pathway. J. Biol. Chem. 274, 20745-20748

20 Müller, L., and Lindberg, I. (2000) The cell biology of the prohormone convertases PC1 and PC2. Prog. Nucleic. Acid. Res. Mol. Biol. 63, 69-108

21 Scamuffa, N., Calvo, F., Chretien, M., Seidah, N.G and Khatib, A.-M. (2006) Proprotein convertases: Lessons from knockouts. FASEB J. 20, 1954-1963

22 Scopsi, L., Gullo, M., Rilke, F., Martin, S., and Steiner, D.F. (1995) Proprotein convertases (PC1/PC3 and PC2) in normal and neoplastic human tissues: Their use as markers of neuroendocrine differentiation. J. Clin. Endocrinol. Metab. 80, 294-301

23 Macro, J.A., Bate, G.W., Varro, A., Vaillant, C., Seidah, N.G., Dimaline, R., and Dockray, G.J. (1997) Regulation by gastric acid of the processing of progastrin-derived peptides in rat antral mucosa. J. Physiol. 502, 409-419

24 Macro, J.A., Dimaline, R., and Dockray, G.J. (1996) Identification and expression of prohormoneconverting enzymes in the rat stomach. Am. J. Physiol. 270, G87-G93

25 Lusson, J., Vieau, D., Hamelin, J., Day, R., Chretien, M., and Seidah, N.G. (1993) cDNA structure of the mouse and rat subtilisin/kexin-like PC5: a candidate proprotein convertase expressed in endocrine and nonendocrine cells. Proc. Natl. Acad. Sci. USA 90, 6691-6695

26 Villeneuve, P., Seidah, N.G., and Beaudet, A. J. (1999) Immunohistochemical distribution of the prohormone convertase PC5-A in rat brain. Neurosci. 92, 641-654

27 Rehfeld, J.F., Lindberg, I., and Friis-Hansen, L. (2002) Progastrin processing differs in 7B2 and PC2 knockout animals : a role for 7B2 independent of action on PC2. FEBS Lett. 510, 89-93

28 Zhu, X., Zhou, A., Dey, A., Norrbom, C., Caroll, R., Zhang, C., Laurent, V., Lindberg, I., Ugleholdt, R., Holst, J.J., and Steiner, D.F. (2002) Disruption of PC1/3 expression in mice causes dwarfism and multiple neuroendocrine peptide processing defects. Proc. Natl. Acad. Sci. USA 99,10293-10298

29 Rehfeld, J.F., Bardram, L., and Hilsted, L. (1992) Ontogeny of procholecystokinin maturation in rat duodenum, jejunum, and ileum. Gastroenterology 103, 424-430

30 Rehfeld, J.F., Stadil, F., and Rubin, B. (1972) Production and evaluation of antibodies for the radioim- munoassay of gastrin. Scand. J. Clin. Lab. Invest. 30, 221-232

31 Rehfeld, J.F. (1998) Accurate measurement of cholecystokinin in plasma. Clin. Chem. 44, 991-1001

32 Rehfeld, J.F., de Magistris, L., and Andersen, B.N. (1981) Sulfation of gastrin : effect on immunoreactivity. Regul. Pept. 2, 333-342

33 Hilsted, L., and Rehfeld, J.F. (1986) Measurement of precursors for alpha-amidated hormones by radioimmunoassay of glycine-extended peptides after trypsin-carboxypeptidase B cleavage. Anal. Biochem. 152, 119-126

34 van Solinge, W.W., and Rehfeld, J.F. (1990) Radioimmunoassay for sequence 38-54 of human progastrin: increased diagnostic specificity of gastrin-cell diseases. Clin. Chim. Acta 192, 35-46

35 Bardram, L., and Rehfeld, J.F. (1988) Processingindependent radioimmunoanalysis: a general analytical principle applied to progastrin and its products. Anal. Biochem. 175, 537-543

36 Goetze, J.P., Hansen, C.P., Rehfeld, J.F. (2006) Antral content, secretion and metabolism of N-terminal progastrin fragments. Regul. Peptides.133, 47-53

37 Bundgaard, J.R., Cowland, J.B., Vuust, J., Rehfeld, J.F. (1996) An efficient cellular system for mutational analysis of prohormone processing. DNA Cell. Biol. 15,147-57

38 Srour, N., Lebel, A., McMahon, S., Fournier, I., Fugère, M., Day, R., and Dubois, C.M. (2003)

TACE/ADAM-17 maturation and activation of scheddase activity require proprotein convertase activity. FEBS Lett. 555; 275-283

39 Shen, F.S., Seidah, N.G., and Lindberg, I. (1993) Biosynthesis of the prohormone convertase PC2 in Chinese hamster ovary cells and in rat insulinoma cells. J. Biol. Chem. 268, 24910-24915

40 Hornby, P.J., Rosenthal, S.D., Mathis, J.P., Vindrola, O., and Lindberg, I. (1993) Immunocytochemical localization of the neuropeptide-synthesizing enzyme PC1 in AtT-20 cells. Neuroendocrinol. 58, 555-563

41 Nielsen, J.E., Hansen, M.A., Jørgensen, M., Tarnaka, M., Almstrup, K., Skakkebaek, N.E., and Leffers, H. (2003) Germ cell differentiation-dependent and stage-specific expression of LANCL1 in rodent testis. Eur. J. Histochem. 47, 215-222

42 Hilsted, L., Bardram, L., and Rehfeld, J.F. (1988) Progastrin maturation during ontogenesis. Accumulation of glycine-extended gastrins in rat antrum at weaning. Biochem. J. 255, 397-402

43 Sawada, M., Finniss, S., and Dickinson, C.J. (2000) Diminished prohormone convertase 3 expression (PC1/PC3) inhibits progastrin post-translational processing. Regul. Pept. 19, 19-28

44 Zhou, A., Bloomquist, B.T., and Mains, R.E. (1993) The prohormone convertases PC1 and PC2 mediate distinct endoproteolytic cleavages in a strict temporal order during proopiomelanocortin biosynthetic processing. J. Biol. Chem. 268;1763-1769 
45 Zhou, A., and Mains, R.E. (1994) Endoproteolytic processing of proopiomelanocortin and prohormone convertases 1 and 2 in neuroendocrine cells overexpressing prohormone convertases 1 or 2 . J. Biol. Chem. 269, 17440-17447

46 Mathis, J.P., and Lindberg, I. (1992) Posttranslational processing of proenkephalin in AtT-20 cells: evidence for cleavage at a Lys-Lys site. Endocrinology 131, 2287-2296

47 Bundgaard, J.R., Birkedal, H., and Rehfeld, J.F. (2004) Progastrin is directed to the regulated secretory pathway by synergistically acting basic and acidic motifs. J. Biol. Chem. 279, 5488-5493

48 Mulcahy, L.R., Vaslet, C.A., and Nillni, E.A. (2005) Prohormone-convertase 1 processing enhances post-Golgi sorting of prothyrotropin-releasing hormone-derived peptides. J. Biol. Chem. 280, 3981839826

49 Nakagawa, T., Hosaka, M., Torii, S., Watanabe, T., Murakami, K., and Nakayama, K. (1993) Identification and functional expression of a new member of the mammalian Kex2-like processing endoprotease family: its striking structural similarity to PACE4. J. Biochem. Tokyo 113, 132-135
50 Cain, B.M., Vishnuvardhan, D., and Beinfeld, M.C. (2001) Neuronal cell lines expressing PC5, but not PC1 or PC2, process Pro-CCK into glycine-extended CCK 12 and 22. Peptides 22,1271-1277

51 Helle, K.B. (2004) The granin family of uniquely acidic proteins of the diffuse neuroendocrine system: Comparative and functional aspects. Biol. Rev. 79, 769-794

52 Tanaka, H., Yoshida, T., Mayamoto, N., Motoike, T., Kurosu, H., Shibata, K., Yamanaka, A., Williams, S.C., Richardson, J.A., Tsujino, N., Garry, M.G., Lerner, M.R., King, D.S., O'Dowd, B.F., Sakurai, T., Yanagisawa, M. (2003) Characterization of a family of endogenous neuropeptide ligands for the $G$ protein-coupled receptors, GPR7 and GPR8. Proc. Natl. Acad. Sci. USA. 100, 6251-6256

53 Mondal, M.S., Yamaguchi, H., Date, Y., Toshinai, K., Kawagoe, T., Tsuruta, T., Kageyama, H., Kawamura, Y., Shioda, S., Shimomura, Y., Mori, M., Nakazato, M. (2006) Neuropeptide W is present in antral G cells of rat, mouse and human stomach. J. Endocrinol. 29, 61-72 
Table 1 Progastrin and its products in antral mucosa of PC1/3 and PC2* null mice, carboxypeptidase E deficient mice ${ }^{\star *}$ and corresponding wild-type mice (pmol/g tissue; mean \pm SEM)

\begin{tabular}{|c|c|c|}
\hline & $\begin{array}{c}\text { PC1/3 knockout } \\
(n=4)\end{array}$ & $\begin{array}{l}\text { Wild-type } \\
(n=4)\end{array}$ \\
\hline Progastrin & $98.0 \pm 49.6$ & $35.8 \pm 7.3$ \\
\hline Gastrin-Gly-Arg & $0.5 \pm 0.3$ & $1.0 \pm 0$ \\
\hline Gastrin-Gly & $3.5 \pm 1.8$ & $10.3 \pm 1.8$ \\
\hline \multirow[t]{2}{*}{ Gastrin-amide } & $145.5 \pm 65.0$ & $568.3 \pm 135.6$ \\
\hline & $\begin{array}{c}\text { PC2 knockout } \\
(n=8)\end{array}$ & $\begin{array}{l}\text { Wild-type } \\
\quad(n=8)\end{array}$ \\
\hline Progastrin & $21.0 \pm 6.5$ & $14.0 \pm 3.5$ \\
\hline Gastrin-Gly-Arg & $0.0 \pm 0.0$ & $0.5 \pm 0.2$ \\
\hline Gastrin-Gly & $6.5 \pm 1.5$ & $5.5 \pm 1.5$ \\
\hline \multirow[t]{2}{*}{ Gastrin-amide } & $750.0 \pm 140.5$ & $650.5 \pm 131.0$ \\
\hline & $\begin{array}{l}\text { CPE-deficiency } \\
\qquad(n=8)\end{array}$ & $\begin{array}{l}\text { Wild-type } \\
(\mathrm{n}=8)\end{array}$ \\
\hline Progastrin & $0.0 \pm 0.0$ & $11.6 \pm 5.2$ \\
\hline Gastrin-Gly-Arg & $1054.0 \pm 122.0$ & $12.2 \pm 6.3$ \\
\hline Gastrin-Gly & $=7.1$ & $4.8 \pm 0.5$ \\
\hline Gastrin-amide & $601.0 \pm 28.0$ & $715.0 \pm 43.0$ \\
\hline
\end{tabular}

* data from ref. $27 ;{ }^{* *}$ data from ref. 18 
Table 2 The site-specific cleavages at dibasic sequences in progastrin by prohormone convertases (PCs) expressed in antral G-cells

\begin{tabular}{lccc}
\hline Prohormone Convertase & $\mathrm{R}_{36} \mathrm{R}_{37}$ & $\mathrm{~K}_{53} \mathrm{~K}_{54}$ & $\mathrm{R}_{73} \mathrm{R}_{74}$ \\
\hline $\mathrm{PC} 1 / 3$ & ++ & - & ++ \\
$\mathrm{PC2}$ & - & + & - \\
$\mathrm{PC} 5 / 6$ & - & - & + \\
\hline
\end{tabular}




\section{LEGENDS TO FIGURES}

\section{Figure $1(A)$ The mouse progastrin sequence}

is given in single letter code with the three dibasic cleavage sites printed in bold and asterisk indicating the single tyrosyl-sulfation site. The bioactive tetrapeptide sequence in the gastrins is boxed.

Figure 1 (B) Diagram of the co- and posttranslational modification of progastrin in antral Gcells

Activation of the gastrin amidation site (-Phe71-Gly72Arg73-Arg74-) occurs via a series of carboxyterminal cleavages and modifications. Endoproteolytic cleavage by prohormone convertases (PCs) produces the carboxypeptidase E substrate (-Phe-Gly-Arg). Carboxypeptidase $\mathrm{E}$ then acts in secretory granules to remove the $\mathrm{C}$ terminal arginyl residue yielding glycine-extended gastrin (-Phe-Gly). Carboxyamidation by PAM subsequently results in the production of bioactive gastrin (-Phe-NH2). Concomitant $\mathrm{N}$-terminal cleavage by PCs produces bioactive gastrins of varying size (e.g. gastrin-34 and gastrin-17). The indications of PC1/3, PC2 and PC5/6 in the diagram is based on the results of the present and an earlier study [27]. A library of sequence-specific antibodies was used in combination with in vitro protease treatment to measure bioactive gastrin and various precursor peptides, as described in the text.

Figure 2 Average percentages of the processing parameters measured in antral extracts of PC1/3 knockout mice

The parameters (progastrin, gastrin-Gly-Arg, gastrin-Gly and bioactive gastrin-amide) are compared with those measured in PC2 knockout mice and in carboxypeptidase $E$ deficient (CPE) mice $[19,28]$, as well as with their respective wild-type controls (broken line at 100\%).

Figure 3. Gel chromatography on Sephadex G50 superfine columns of antral extracts from PC1/3 knockout mice (left panels) and from corresponding wild-type control mice (WT, right panels)

The chromatographic elutions were monitored using antibody 2604 that binds carboxyamidated gastrins (the bioactive gastrins), irrespective of the degree of tyrosylsulfation (upper panels) and antibody 2605 that binds only non-sulfated (ns) gastrin (lower panels). Antral extracts from four different mice in each of the two groups
(PC1/3 and controls) were subjected to chromatography. Extracts containing similar amounts of gastrin were applied to the columns. Those shown above are characteristic of each group.

Figure 4. Gel chromatography on Sephadex G50 superfine columns of antral extracts from PC1/3 knockout mice (KO, upper panel) and littermate wild-type controls (WT, lower panel)

The chromatographic elutions were monitored using antibody 5284 that binds glycine-extended gastrins after trypsin and carboxypeptidase B treatment of each fraction. Antral extracts from four different mice in each of the two groups ( $\mathrm{PC} 1 / 3$ and controls) were subjected to chromatography. Those shown are characteristic of each group.

Figure 5 Gel chromatography on Sephadex G-50 superfine columns of human progastrin before and after incubation with recombinant PC5/6

The chromatographic elution was monitored by a radioimmunoassay specific to the intact $\mathrm{N}$-terminus of human progastrin using antiserum No. 94023 (ref. 36). The upper panel shows the elution without prior treatment with PC5/6. The lower panel shows the elution after treatment with $\mathrm{PC} 5 / 6$, which has been shown to cleave a relevant control peptide.

\section{Figure 6 Gastrin and PC1/3 co-localization}

Gastrin (green) co-localizes with PC1/3 (red) (Panel A). Gastrin (green) also co-localizes with PC2 (red) (Panel $B)$. In contrast to $P C 1 / 3$, which is mainly found in the antral G-cells, many other antral endocrine cells also express PC2 (Panel B). (Spacebar $50 \mu \mathrm{m})$. Gastrin was identified with antibody no. 8007.

\section{Figure $7 \quad$ Gastrin and PC5/6 co-localization}

Serial sections were examined for PC5/6 expression by in situ hybridisation (Panel A) and gastrin expression by immunohistochemistry (Panel B). Panel C shows the $\mathrm{PC5} / 6$ in situ using the sense probe. The black arrows point to cells that express both PC5/6 and gastrin (Panel $A$ and $B)$. The white arrow identifies a cell expressing PC5/6 but not gastrin (Panel A and B). (Spacebar 50 $\mu \mathrm{m})$. Gastrin was identified using antibody no. 8007 


\section{Figure 1}

A

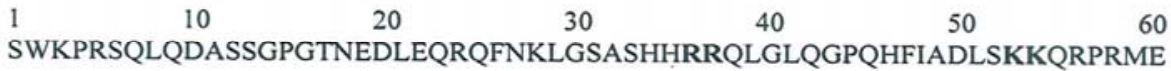
* $70 \quad 80$

B

PREPROGASTRIN

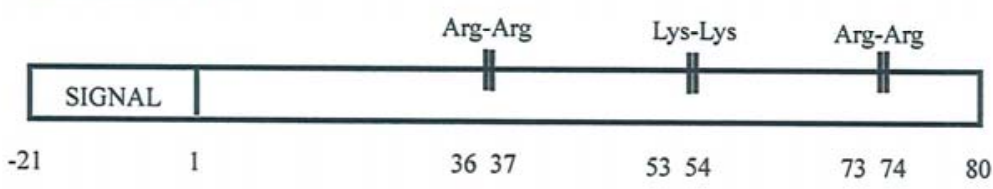

ROUGH ENDOPLASMIC RETICULUM:

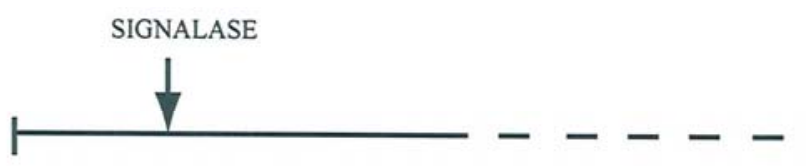

TRANS-GOLGI APPARATUS:

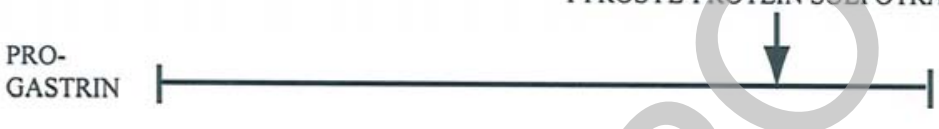

IMMATURE SECRETORY VESICLES:

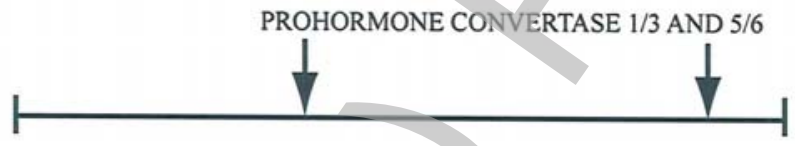

SECRETORY GRANULES:

Gly $_{72}$-Arg $_{73}$ INTERMEDIATE

Gly $_{72}$ INTERMEDIATE

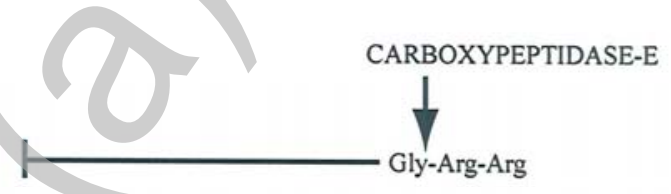

PROHORMONE

CONVERTASE 2 AND $5 / 6$ PEPTIDYLGLYCINE a-AMIDATED

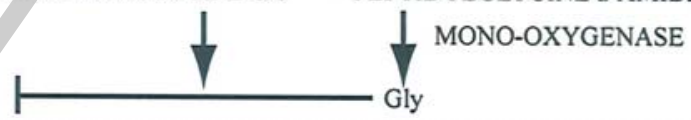

BIOACTIVE GASTRINS

$(-34$ AND -17$)$

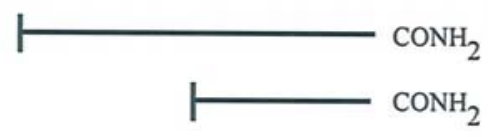

Licenced copy. Copying is not permitted, except with prior permission and as allowed by law. (C) 2008 The Authors Journal compilation (C) 2008 Biochemical Society 
Figure 2
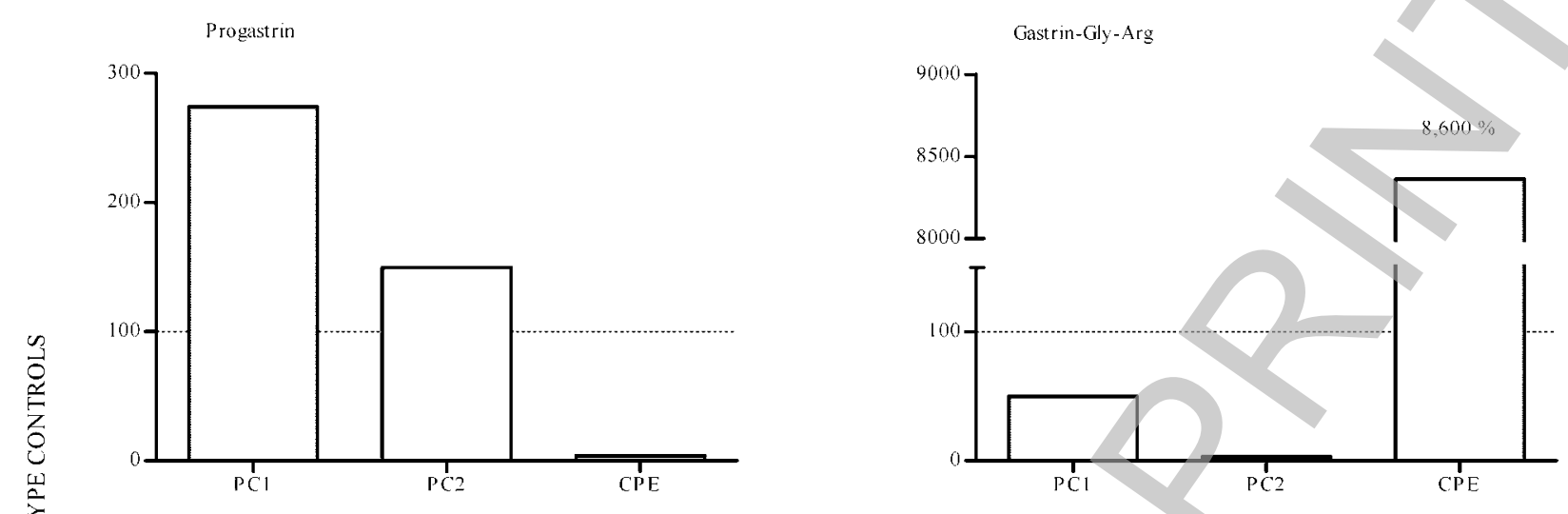

章

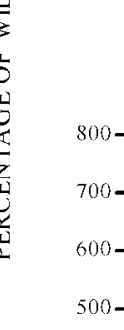

Gastrin-Gly

Gastrin-amide

$723 \%$
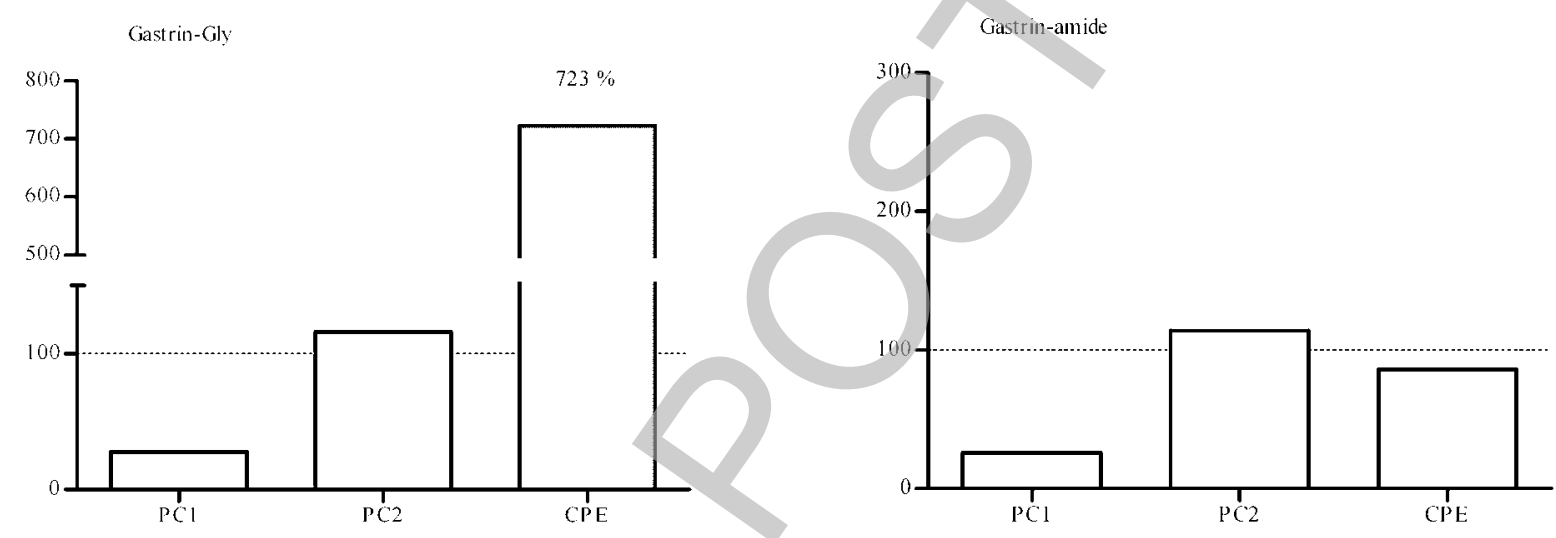

Licenced copy. Copying is not permitted, except with prior permission and as allowed by law. (C) 2008 The Authors Journal compilation (C) 2008 Biochemical Society 
Figure 3

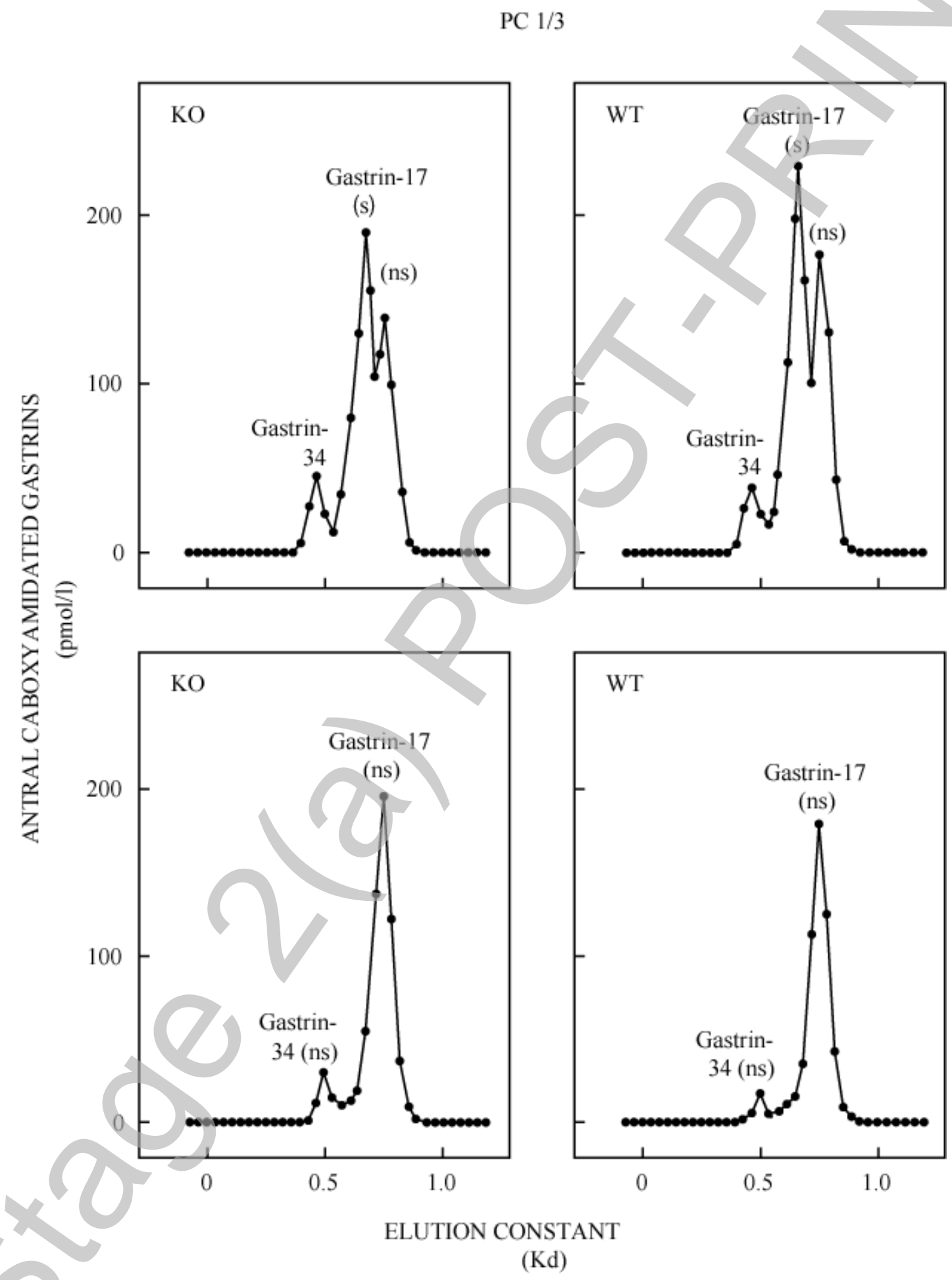

Licenced copy. Copying is not permitted, except with prior permission and as allowed by law. (c) 2008 The Authors Journal compilation (c) 2008 Biochemical Society 
Figure 4

PC $1 / 3$

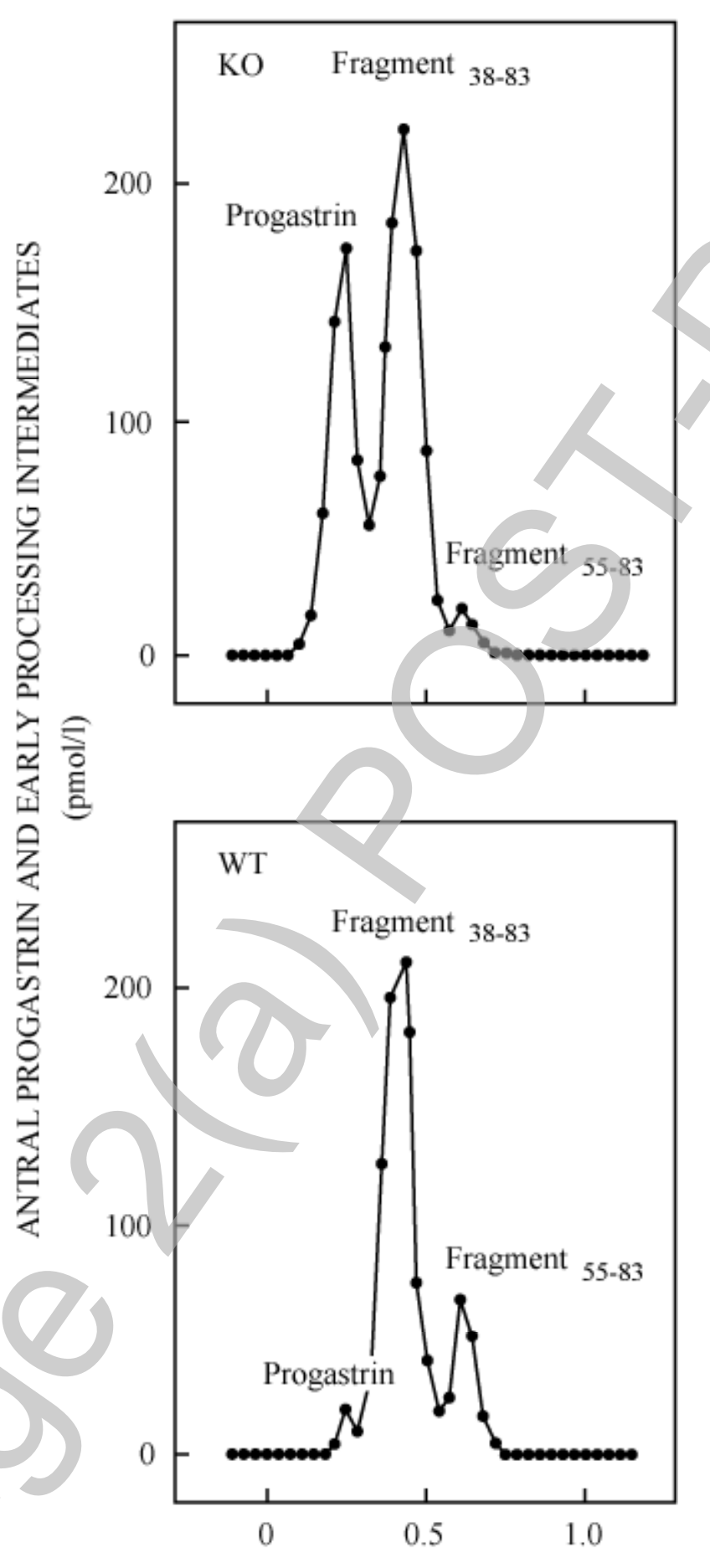

ELUTION CONSTANT

(Kd) 
Figure 5

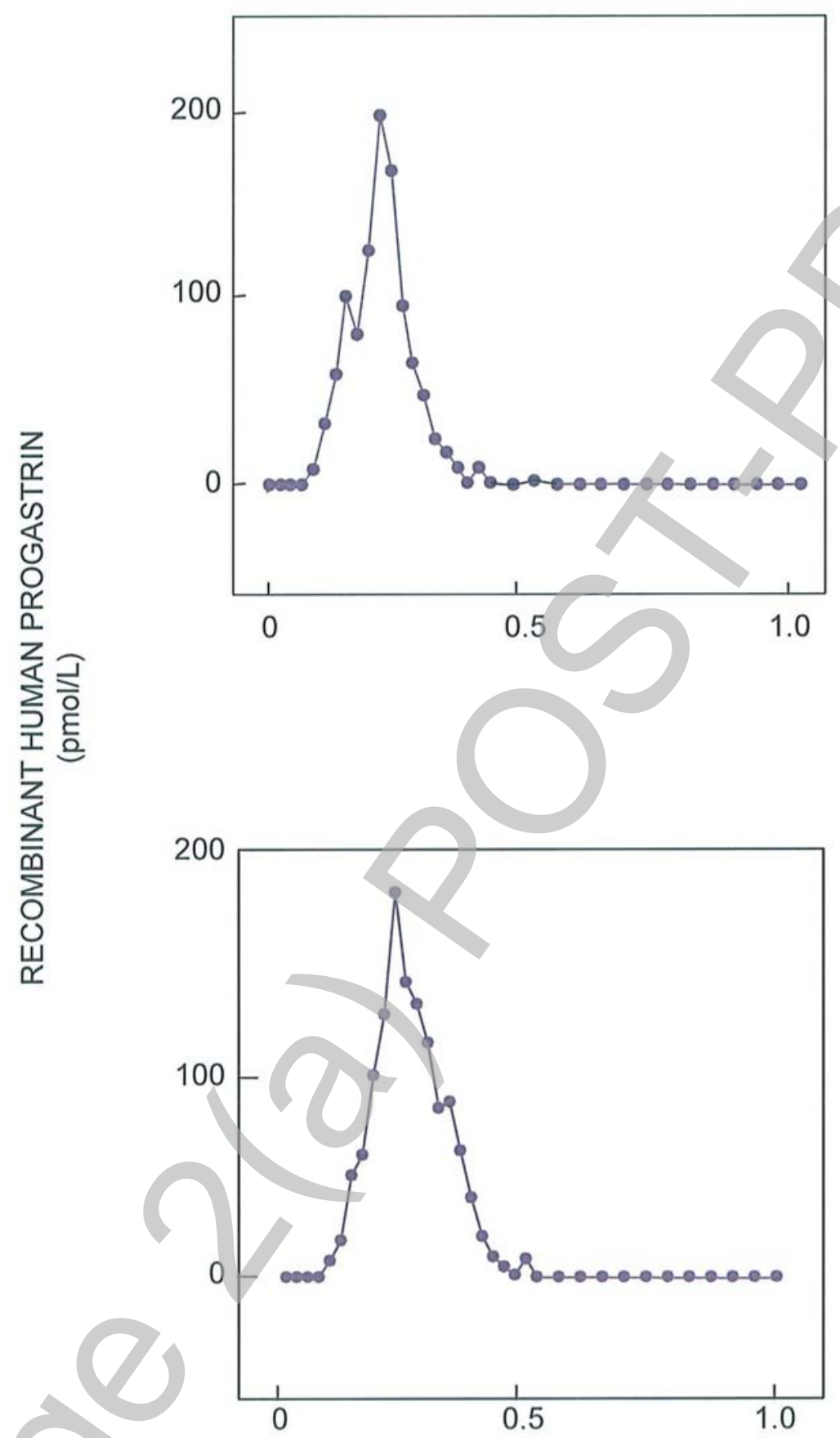

Licenced copy. Copying is not permitted, except with prior permission and as allowed by law. (C) 2008 The Authors Journal compilation (C) 2008 Biochemical Society 
B Biochemical Journal Immediate Publication. Published on 13 Jun 2008 as manuscript BJ20080881

Figure 6

G-CELLS

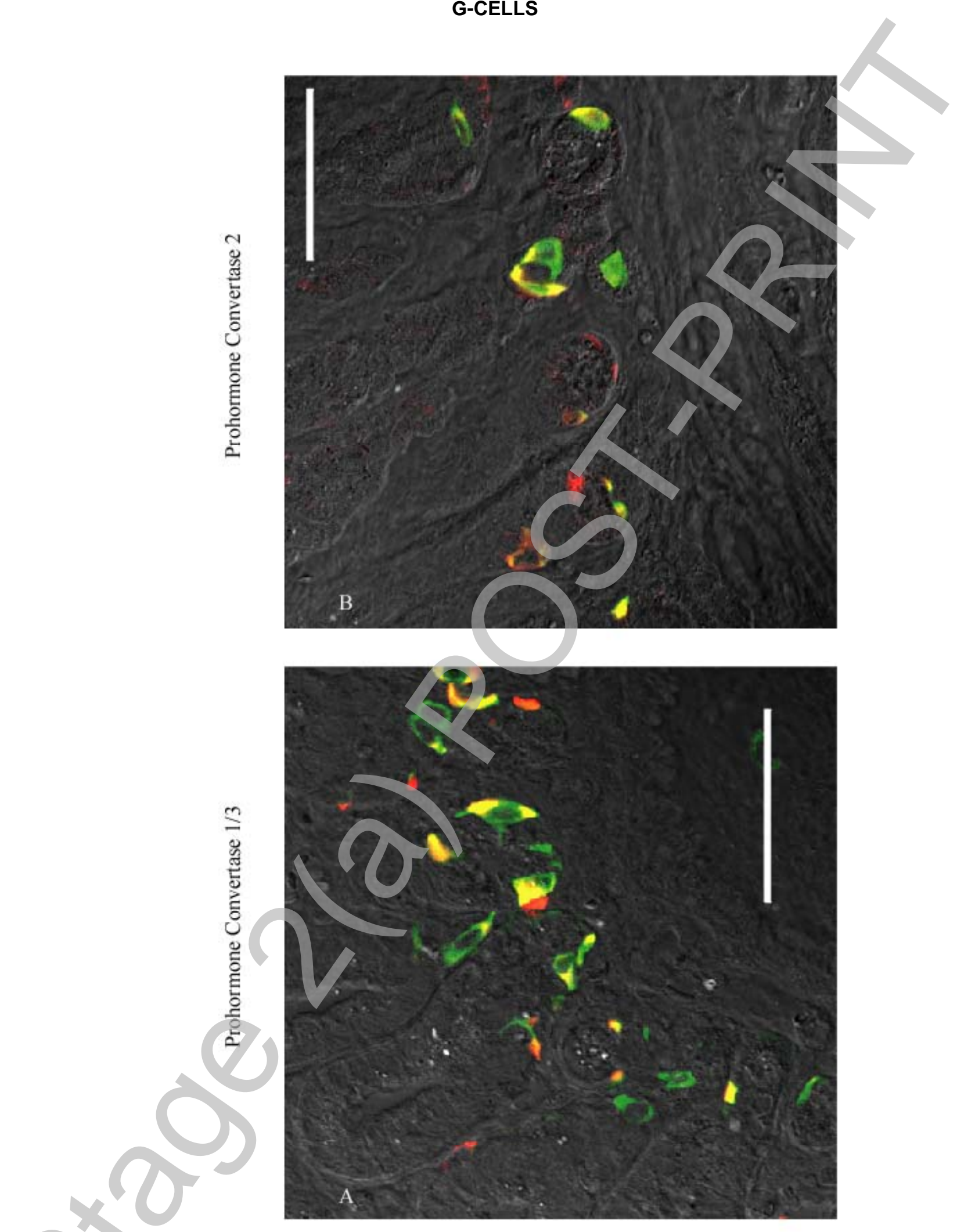


Figure 7

G-CELLS
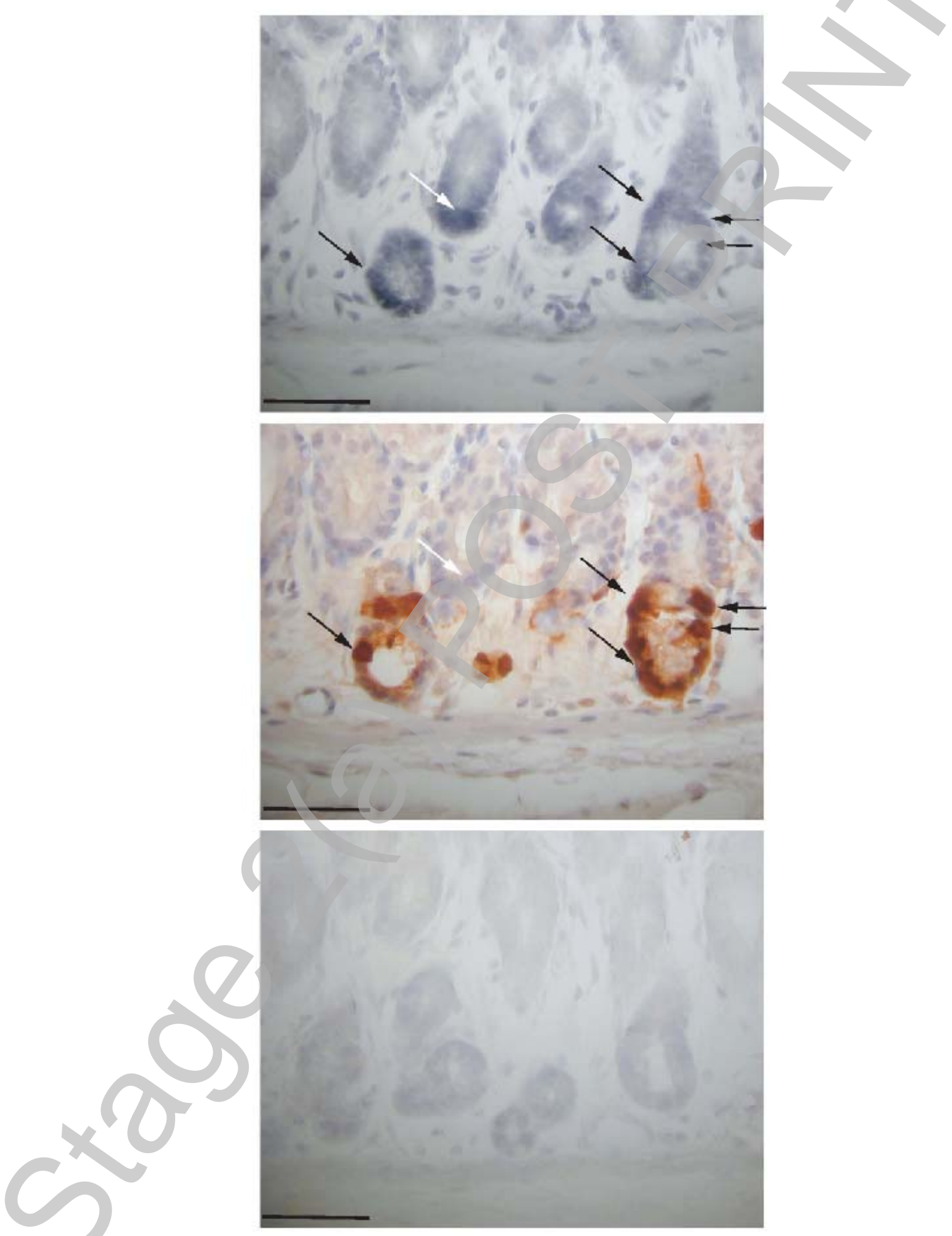

Licenced copy. Copying is not permitted, except with prior permission and as allowed by law. (C) 2008 The Authors Journal compilation (C) 2008 Biochemical Society 